\title{
THE CONSTITUTION OF JAPAN, AT THE FOUNDING AND 50 YEARS LATER
}

Lawrence W Beer

This is a revised version of a paper presented by Professor Beer at a combined meeting of the New Zealand Institute of Public Law and of the New Zealand Association for Comparative Law in the Faculty of Law, Victoria University of Wellington, New Zealand in August 1996.

\section{INTRODUCTION}

Fifty-one years ago this week the Second World War ended. Shortly thereafter, Japan experienced its second modern constitutional revolution. The first occurred in 1868 when feudal leaders destroyed their own class system and unified the country under an ahistorical, transformed Emperor institution. ${ }^{1}$ Fifty years ago, Japan's parliament, the Diet, was busy finalizing the present Constitution of Japan. That Constitution has been in effect without amendment since May 3, 1947, making Japan's one of the twenty oldest of the world's 181 single-document national constitutions. It has been the most trusted, respected and legitimized of Japan's national institutions since its founding during the Allied Occupation (1945-52). ${ }^{2}$

Because it rarely generates income or media hype, few legal scholars and practitioners have noticed that over 130 of the world's constitutions have been ratified since 1970. Other nations, like New Zealand, have been in the process of refining or rethinking their basic law in recent times, or should be doing so, like the United States. With respect to human

* Fred Morgan Kirby Professor of Civil Rights, Lafayette College, United States of America.

1 On the development of Japan's modern law and first constitution, see Masami Ito in LW Beer (ed) Constitutional Systems in Late Twentieth Century Asia (Seattle \& London, University of Washington Press, 1992) 129-174.

2 LW Beer "Constitutionalism and Rights in Japan and Korea" in L Henkin \& A Rosenthal (eds) Constitutionalism and Rights: The Influence of the United States Constitution Abroad (New York, Columbia University Press, 1990) 225-259; J Marshall Japan's Successor Generation: Their Values and Attitudes (USIA Report, 1985). 
rights provisions, the American Constitution is anachronistic and strangled in legalisms without a coherent basis in constitutional principle; but the powerful legal fraternity, as in lesser degree in other common law countries, will not allow adequate tampering with ancient writ. The United States is based on three sacred writs: the Bible, the Declaration of Independence, and the Constitution. Paradoxically, interpretations of the latter are at odds with the other two documents due in part to the destructive intrusion upon the constitutional culture of varied forms of laissez-faire capitalism since the nineteenth century.

That admitted, what is more important and too seldom noted is that we live in the most exciting period of world history with respect to dynamic, diverse and imaginative experimentation with constitutional documents, as most nations converge on a relatively few models concerning the essential institutions of modern statecraft and law. The level of transcultural knowledge and mutual understanding achieved today in the global professional community of law was unimaginable a mere century ago. Comparative constitutional studies is now surely one of the most promising areas of legal research. Among points of agreement with almost all of the world's nations is that a single-document national constitution is close to essential. It is the best way ever devised to set out before citizens and the world what counts most in a nation's coherent principles and structures of law and government. Deviating from the consensus are a very few misguided states: the United Kingdom, New Zealand, Israel, and three countries which count the Quran as their constitution, Saudi Arabia, Libya, and Oman. The contention of the few that a constitution does not matter does not test out theoretically or empirically for most countries. New Zealand's impressive Bill of Rights Act 1990 and Human Rights Act 1993 are best seen not as an alternative to a single-document constitution, but as sensible steps in a process leading to a single comprehensive document expressing in refined form New Zealand's aspirations and institutions for human rights constitutionalism. ${ }^{3}$

While a single-document constitution is essential and useful, it seems to be only part of what should be understood as a nation's "constitution", even where such a document provides a reasonably accurate guide to State behaviour. A more ecological definition of a "living constitution" might be: a nation-state's written and unwritten principles and rules, institutions and processes for organizing, exercising, and (in a genuinely "constitutionalist" state) limiting governmental and community power on behalf of the primary public value(s) of the country in a promulgated and reasonably predictable manner. Examples of such foundational public values that have been suggested are: for Germany, human dignity; for Canada, fraternity; for Australia, "the fair go"; for the United States, liberty and "the sale";

3 G Huscroft \& P Rishworth Rights and Freedoms (Wellington, Brookers, 1995); P Spiller, J Finn \& R Boast A New Zealand Legal History (Wellington, Brookers, 1995). 
and for Japan, consensus. What might be most fundamental to the Kiwi constitutional culture? What the distinctive emphasis?

Be that as it may, besides the most basic constitutional document, a nation's constitution might be considered as including the enabling laws of branches of government, key judicial decisions, Codes in civil law countries like Japan and other East Asian nations and other documents accepted as seminal. For example, in New Zealand perhaps the 1840 Treaty of Waitangi and the 1893 grant of female suffrage, shockingly deviant for its time, should somehow be referred to in a New Zealand Constitution. This expanded notion of a living constitution should lead us to a correspondingly broader than common understanding of who are "the founders" of a nation-state and who "the authors" of a constitution. In what follows, I would illustrate the above themes with the case of Japan in the past fifty years.

Japan's constitutional revolution AWAY FROM wartime (especially 1930-1945) repressive authoritarianism, ultra-nationalism, aggressive militarism, and a state centred on a quasi-divine Emperor AND TOWARD democracy, quasi-pacifism, and enforced and promoted human rights began many months before the Constitution of Japan was promulgated. ${ }^{4}$ The peaceful revolution began with directives (shirei) issued by Occupation authorities to the Japanese government in September and October, 1945. Unlike postsurrender Germany and liberated Korea which were governed directly by the Allied Powers, Japan was indirectly ruled by the office of SCAP (Supreme Commander for the Allied Powers) through directives to Japan's leaders. These directives were called "SCAPIN", and they were converted into Japanese law and policy by Japan. The so-called "freedom orders" (jiyu no shirei), SCAPIN 66 and 93 of September and October 1945, forced Japan's lame-duck government to end censorship and all repressive laws and police systems. Thus, a few Occupation functionaries monitoring the government early in the Occupation are among the "founders" of Japan's present constitutional system, because they served as an essential catalyst instigating fundamental systemic change to a radically new but soon accepted status quo. Analogously, the December 1945 House of Representatives Election Law, which gave women 20 or older the right to vote for the first time, is a document of constitutional importance and status.

The actual writing of the present Constitution of Japan began around February 3, 1946 after rejection by the US government and (SCAP) Gen Douglas MacArthur of cosmetic changes in the Meiji Constitution 1889 which were proposed by Japan pursuant to the surrender acceptance of the Potsdam Declaration (July, 1945). Led by Col Charles Kades and two other attorneys, about twenty American civilian and military personnel wrote in secret a draft constitution in about ten days, which was then substantially revised in

4 Beer, above n 2; LW Beer Freedom of Expression in Japan: A Study in Comparative Law, Politics, and Society (Tokyo \& New York: Kodansha International, 1984) 70-99. 
dialogue with Japanese in and out of government into the month of March. Over thirty major changes were made by Japanese, then and later. The Constitution was not "imposed" on Japan by the United States.

On April 6 a new House of Representatives was elected under the new election law of the previous December. This was the most representative public body in Japanese history; it freely debated, amended and then approved the Constitution of Japan by a vote of 421-8, without American interference. Other "founders" were Japanese and Americans who authored basic implementing legislation such as the Court Law (Saibanshoho) and the democrarized Code of Criminal Procedure (Keijisoshoho). From that beginning to the present, the Constitution of Japan (Nihonkoku Kempo) has been warmly welcomed by an overwhelming majority of Japanese in its multi-document nature. ${ }^{5}$

Fifty years later, what is the record? How well has Japan observed the spirit and letter of the Constitution of Japan? Imperfectly, of course; but in general and by comparative standards of democracy, peaceable international relations, and human rights constitutionalism, Japan's record is very good. Before suggesting a few key issues in Japanese constitutional law especially worthy of foreign legal study, I would offer a few facts too often overlooked by some foreign and Japanese critics of Japan. These facts establish that Japan has been one of the most successful great powers in the world in the past fifty years, perhaps the most successful.

First, no world power has been more peaceable in its international relations than Japan under article 9, the "no war clause" of the "Peace Constitution". Remarkably, Japan has never threatened or used physical force to settle international disputes.

Second, the Constitution is referred to as the "Peace Constitution", but it is as much a "Freedom Constitution". Chapter 3, articles 11 to 40 guarantee Japanese a broad array of individual rights and freedoms. Usually, these freedoms are honored in practice by the government and taken for granted. Articles 14 and 24 granting equal rights for women went well beyond even the progressive views of the "New Deal" Democrats among the occupationnaires like Charles Kades. These women's rights provisions, which have guided a radical improvement in women's status, are due to the improbable influence of Beate Sirota, a 22-year-old college graduate, on both Japanese and American participants in the constitution drafting on March 4 and 5, 1946. Incidentally, by reading Chapter 3 on rights and duties you can get a good idea of American progressive thinking about individual rights after the Second World War when idealism ran high (though not so high as to favour

5 On unsuccessful revision efforts, see LW Beer "Introduction: Japan's Constitutional Law, 19451990" in LW Beer and H Itoh The Constitutional Case Law of Japan, 1970 Through 1990 (Seattle \& London, University of Washington Press, 1996) 12-18. 
constitutional protection of women's rights). After the great "Civil Rights Movement" of the 1950s and 1960s on behalf of African-American and other disadvantaged minorities, the United States has unfortunately backed down from firm commitment to some rights in the 1980s and 1990s.

Third, Japan's superior prowess in many fields of endeavour (other than Olympic sports) is well known. After the United States, Japan affects the world's economy and technology more than any other country. Japan is the leading creditor nation, and the leading provider of non-military foreign aid under the ODA (Official Development Assistance) guidelines of the OECD (Organization for Economic and Cooperation and Development). Japan's United Nations bills are second in size to America's, but unlike the United States' bills, Japan's are paid on time.

However, a more legitimate test than wealth and prowess from the standpoint of Japanese citizens and of comparative constitutional performance is the size of the gap between the rich and the poor in a country. According to a number of studies, Japan shows the smallest gap between the wealthiest $10 \%$ and the poorest $10 \%$ of its population. Whatever the causes, in Japan this is seen as in conformity with requirements of article 25 of the Constitution, ${ }^{6}$ which establishes a right to "minimum standards of wholesome and cultured living". Sadly, among the industrialized democracies, the income gap between rich and poor is greatest in the United States.

Fourth, Japanese have enjoyed an uninterrupted chain of national and local elections under democratic law since 1946, a record matched by relatively few nations anywhere.

In short, although Japan like the other most successful democracies has problems, her record of conforming with the Constitution of Japan is good and merits serious study by constitutional lawyers in other countries. Particularly noteworthy is that Japan has successfully fused together a new creative synthesis of East Asian legalism, civil law, common law, and human rights constitutionalism.

I respectfully suggest that you look carefully at the constitutional case law of Japan. Well over 100 important judicial decisions are readily available in English, as well as

6 Article 25 of the Constitution of Japan:

All people shall have the right to maintain the minimum standards of wholesome and cultured living.

2 In all spheres of live, the States shall use its endeavours for the promotion and extension of social welfare and security, and of public health.

Article 26 establishes a right to free compulsory education, while articles 27 and 28 spell out worker rights to organize and to act collectively. Beer \& Itoh, above n 5, pp 653-665. 
explanations and analyses of many more cases not translated. ${ }^{7}$ The holdings of the Supreme Court of Japan and other courts in exercise of their powers of independent judicial review constitute the most authoritative statements in Japan on many global problems of the world's second most influential country. The Supreme Court, along with the Constitution itself, are Japan's most widely trusted national institutions; party politicians, other than one's own parliamentary representative, are the least respected. ${ }^{8}$ Critics, sometimes including myself, claim the courts are not vigorous enough at times in protecting rights by striking down legislation or other official acts as unconstitutional. A few have exaggerated the relevance and influence of the Cabinet for the independent courts. In fairness, two factors might well be noted: Japan's system balances legal traditions of parliamentary supremacy and judicial supremacy under a Constitution giving strong emphasis to both individual and community responsibility for rights and freedoms. Second, Japan has a Cabinet Legislative Bureau which monitors every phrase of every bill for constitutionality before it goes to parliament for consideration. They rightly prefer to avoid constitutional ambiguity during the legislative process. Such ambiguity would burden the courts with the task of resolving controversial issues, as happens at times in the US Congress.

A second topic worthy of foreign study is the thought-provoking manner in which Japan under article 9 of the Constitution has adhered to a pledge to "forever renounce war ... and the threat or use of force as a means of settling international disputes". 9 Japan's unique

7 Beer \& Itoh, above n 5, Appendix 4 lists over 100 judicial decisions translated into English, with holdings. See also J Maki (ed) Court and Constitution in Japan: Selected Supreme Court Decisions 19481960 (Seattle \& London, University of Washington Press, 1964); H Itoh \& LW Beer The Constitutional Case Law of Japan: Selected Supreme Court Decisions, 1961-1970 (Seattle \& London, University Washington Press, 1978); DF Henderson (ed) The Constitution of Japan: Its First Twenty Years, 1947-1967 (Seattle \& London, University of Washington Press, 1969); N Ashibe, L Beer \& M Itoh "Japan" in Beer, above n 1; P Luney \& K Takahashi (eds) Japanese Constitutional Law (Tokyo; University of Tokyo Press, 1993); H Itoh The Japanese Supreme Court: Constitutional Policies (New York, Markus Wiener Publishing, 1989); DM O'Brien To Dream of Dreams: Religious Freedom and Constitutional Politics in Postwar Japan (Honolulu, University of Hawaii Press, 1996); Beer Freedom above $n 4$.

8 Marshall, above $\mathrm{n} 2$.

9 Article 9 of the Constitution of Japan:

Aspiring sincerely to an international peace based on justice and order, the Japanese people forever renounce war as a sovereign right of the nation and the threat or use of force as a means of settling international disputes.

2 In order to accomplish the aim of the preceding paragraph, land, sea, and air forces, as well as other war potential, will never be maintained. The right of belligerency of the state will not be recognized.

Beer \& Itoh, above n 5, p 655. 
record is only partially explained by the geopolitical good luck essential to any realistic scenario of quasi-pacifism in a great power. Japan's quasi-pacifism is an extraordinary phenomenon and constitutes Japan's one original contribution to constitutionalist thought and practice in world civilization. Japan has not fired a shot in anger since 1945, a radical turnaround for the most aggressively militarist of non-Western powers in the previous half century.

Japan's military budget is statistically large because of its enormous GNP; but with the limit set at $1 \%$ of GNP, Japan is weak in East Asian military geopolitics, even compared to Taiwan. Moreover, Japanese weaponry may not be exported, to Japan's considerable economic loss. No nuclear weapons may be introduced, possessed or made by Japan under policy since the reversion of Okinawa in 1972. The laws and Constitution of Japan contain no provisions on making war or peace, and operate on a basic assumption that Japan is not militarily threatened by any country. The hotly debated 1992 law enabling Japan's participation in United Nations Peace-keeping Operations is severely restrictive. Only with prior parliamentary approval of each mission may small numbers of Self-Defence Force (SDF) members join in monitoring an achieved ceasefire; any breakdown of a ceasefire triggers an immediate return to Japan. Even the constitutionality of the small and decreasing air, land, and sea SDF is still questioned by the majority of Japan's constitutional lawyers and by some politicians, ${ }^{10}$ but not by the great majority of Japanese. Polls indicate the public supports the constitutionality of the SDF as long as it is small, helps in time of natural disaster, and does not engage in fighting abroad. Over $80 \%$ of Japanese voice support for the practical idealism of article 9 in 1996.

With the end of the Cold War and the colonial period, the world is in a messy transitional time without much order. But this is also a time of exceptional opportunity for many nations which have long lacked elbow room in their international relations due to super power or colonialist pressures. Without undue optimism but also without a useless and equally unrealistic cynicism, now may be the time for all nations to adopt a constitutional provision renouncing war and the threat or use of force as means of settling international disputes. Some nations are reexamining comprehensively their genuine national security needs seeking a credible answer to the question: Which specific countries pose a real military threat if any? Many nations like Japan define national security as primarily dependent on social, economic, technological and ecological factors. The US-

10 Some constitutional lawyers allege SDF unconstitutionality on the technical grounds of reasonable legal interpretation of the words of article 9; others oppose the SDF on both constitutional and policy grounds; and still others do not find the SDF's existence constitutionally repugnant but consider it unwise policy. A learned pacifist exposition is T Fukase Senso Hoki to Heiwateki Seizonken (Renunciation of War and the Right to a Peaceful Life) (Tokyo, Iwanami Shoten, 1987). See also J Auer "Article 9: Renunciation of War" in Luney \& Takahashi, above n 7, at p 69. 
Japan Security Treaty contributes to Asian security, but Japanese and American perceptions of issues and benefits diverge. Some countries need no purely military force, many others need far less war potential than they have. Military politics distorts constitutional politics in the US more than in Japan, but less severely than in Burma, Indonesia, India, Pakistan and China. In Asia, the principal function of some militaries is not defence, but maintenance of control and stability.

Finally, a third area of Japanese constitutional law and politics which has received and warrants foreign study, for both the strengths and the weaknesses it reveals in Japan's constitutional culture, is criminal justice rights. ${ }^{11}$ On the one hand, Japan is a very safe and democratic place to live. The police are user-friendly and respected, perhaps most helpful in giving directions at the police boxes in labyrinthine urban neighbourhoods. Japan's crime rate is low and its prison population is very small. Its compassionate leniency and emphasis on reintegration of offenders into the community are impressive under laws and processes which are not suffused with vengeance and punishment. The training, dedication, ability, and integrity of Japan's police, prosecutors, judges and attorneys are generally of as high a level as any in the world. The overwhelming majority of suspects never go to trial, let alone prison, in a great many cases despite ample proof of guilt.

On the other hand, there is a seminal problem of power balance and supervision among police, prosecutors, and judges. Police and prosecutors dispose of many more cases than judges, who thus by effect hand down convictions in almost all criminal cases. As the system operates, prosecutors exercise a quasi-judicial function through a delay of prosecution (kiso yıyo) technicality which commonly ends action in felony cases. Most important perhaps, police, prosecutors, and even judges seem to place too great emphasis on full and remorseful confessions, as the proper indicator of sorrow and intent to reform and as the condition for leniency. The effect of this emphasis is heightened by severely limited access to an attorney. A detained person does not have a right to an attorney until formally indicted (kiso), and even then only for a limited number of short periods. The worst abuses are thought to occur before indictment.

The case clearance rate in Japan is outstanding., but in a minority of cases police, with judicial warrant routinely given but without careful prosecutorial monitoring, can keep a person under interrogation for over twenty days in pursuit of an adequate confession, without bail or attorney assistance. Detainees are often kept in "alternative detention facilities" (daiyo kangoku; also called "substitute prisons"), and may be mistreated; a proposal to require videotaping of all interrogations is not expected to be adopted. The roles of judges and defence attorneys seem to need reemphasis. The spirit of the criminal

11 Beer \& Itoh, above n 5, pp 25-29, 63-65. 
justice rights set forth in articles 31 to 40 of the Constitution is not yet adequately honoured; that may be Japan's key constitutional problem in the 1990s.

Malapportionment was a major concern of many constitutional lawyers until the historic election law reforms in 1994; a great discrepancy in the value of a vote in different election districts had arisen. ${ }^{12}$ With respect to what are called "rights and freedoms of the spirit" (seishinteki jiyuken), the freedoms of expression, assembly, association, religion, academic research and university teaching, petition and protest, thought, conscience and press have been vigorously enjoyed for over fifty years free of any noteworthy government restraints in all but very few contexts. A few such exceptions have been the ban on door-todoor vote canvassing, limitation on civil servant political activities related to voting, and Education Ministry tampering with pre-1945 history in high school textbooks. In such continuing national debates, the courts play a central role. ${ }^{13}$

As in any constitutional democracy, Japan's social culture contains some elements which strengthen and other elements which weaken the status of human rights and constitutionalism. ${ }^{14}$ A non-individualist groupism militates against authoritarian leadership and assures coherent group advocacy of diverse interests. The powerful emphasis on achieving consensus favours broad-based participation in debates, both national and within in-groups; but once consensus is achieved, there is less tolerance for dissent or for opposing groups.

Japan has proven to be impressively egalitarian in its socio-economic life. Small minorities continue to experience occasional discrimination, as do women; but many of the guiding elites have persistently worked to improve in these and other areas of concern, and with notable successes. "Improve always" is not only a slogan of Japan's auto and computer makers. It is the imperative of a constitutionalist people with a very low threshold of tolerance for their country's mistakes or for the considerable international shame brought on by poor performance in human rights, as with respect to criminal justice. In another fifty years, new constitutional concerns will likely replace those of the present, but we can hope that Japan's freedom revolution and quasi-pacifism will continue, that single-document constitutions will express further convergence in world community-building processes, and that the communications revolution will ease useful development of comparative

12 On malapportionment, see Beer \& Itoh, above n 5, cases 22, 23 and 24 and pp 38-41.

13 Beer \& Itoh, above n 5, cases 16, 17, 18, 36,37 and 43, and pp 36-38, 44-49.

14 Beer Freedom above n 4, pp 100-128; L Beer "Freedom of Expression: The Continuing Revolution" in Luney \& Takahashi, above n 7, at pp 243-254; D Bayley Forces of Order: Policing Modern Japan (Berkeley, University of California Press, 1991); VL Hamilton \& J Sanders Everyday Justice: Responsibility and the Individual in Japan and the United States (New Haven \& London, Yale University Press, 1992). 
constitutional studies. If so, it may not be too much to expect that Japan's constitutional law will be as routinely mentioned in the course of legal education in New Zealand, Australia and other world regions, as foreign civil law and common law have been studies in Japan in the past fifty years. As the world's prime example of successful synthesis of radically different traditions of law and constitution, surely Japan deserves global respect and much more study in the emerging multi-cultural age. 